\title{
Effects of Chlorpyrifos Ethyl on Cholinesterase and Growth of Silver Barb (Barbonymus gonionotus)
}

\author{
Nguyen Van Cong *, Dinh Thai Danh and Tran Sy Nam (]) \\ College of Environment and Natural Resources, Can Tho University, Campus II, $3 / 2$ Street, Can Tho City 92000, \\ Vietnam; dtdanh@ctu.edu.vn (D.T.D.); tsnam@ctu.edu.vn (T.S.N.) \\ * Correspondence: nvcong@ctu.edu.vn
}

Citation: Cong, N.V.; Danh, D.T.; Nam, T.S. Effects of Chlorpyrifos Ethyl on Cholinesterase and Growth of Silver Barb (Barbonymus gonionotus). Water 2021, 13, 2885. https://doi.org/10.3390/ w13202885

Academic Editor: Anna Barra Caracciolo

Received: 30 September 2021 Accepted: 11 October 2021 Published: 14 October 2021

Publisher's Note: MDPI stays neutral with regard to jurisdictional claims in published maps and institutional affiliations.

Copyright: (c) 2021 by the authors. Licensee MDPI, Basel, Switzerland. This article is an open access article distributed under the terms and conditions of the Creative Commons Attribution (CC BY) license (https:/ / creativecommons.org/licenses/by/ $4.0 /)$.

\begin{abstract}
Chlorpyrifos ethyl is a popular insecticide widely used in agriculture within the Vietnamese Mekong delta, including for rice farming. Here, local farmers often apply pesticides at very high rates which leads to contamination of the surrounding environment. Silver barb (Barbonymus gonionotus) is a fish species indigenous to the delta, which resides in a variety of water bodies and is also commonly cultivated in rice-fish systems. As a result, this species is at high risk of exposure to chlorpyrifos ethyl. This study aims to determine the lethal concentration $\left(\mathrm{LC}_{50}\right)$ of chlorpyrifos ethyl, as well as the effects of sub-lethal concentrations on the activity of cholinesterase and growth of Silver barb. Lethal concentration testing was conducted in a static non-renewed system. Three concentrations of chlorpyrifos ethyl (1\%, 10\% and 20\% LC50-96 h) were conducted in triplicate to assess the effects of chlorpyrifos ethyl on the brain cholinesterase (ChE) of fingerling fish for 15 days, and on their growth for 60 days. Results showed that chlorpyrifos ethyl was highly toxic to fingerling Silver barb with a $\mathrm{LC}_{50}-96 \mathrm{~h}$ of $0.119 \mathrm{ppm}$. The lowest observed effect concentration (LOEC) was $1 \% \mathrm{LC} 50-96 \mathrm{~h}$ for $\mathrm{ChE}$ and 10\%LC50-96 h for growth. No observed effect concentration (NOEC) of chlorpyrifos ethyl for growth was $1 \% \mathrm{LC} 50-96 \mathrm{~h}$. The result from this study suggests that $\mathrm{ChE}$ activity is significantly inhibited at environmentally realistic concentrations in the Vietnamese Mekong delta and can be used as a biomarker of pesticide exposure. Further study in the rice fields as well as in the canals or rivers is required.
\end{abstract}

Keywords: chlorpyrifos ethyl; cholinesterase; $\mathrm{LC}_{50}$; growth; Barbonymus gonionotus; toxicity

\section{Introduction}

The Vietnamese Mekong delta (VMD) in southern Vietnam is an area of intense rice cultivation for both domestic consumption and export. Intensive rice cultivation has been developed and promoted over the last 30 years with two to three crops per year. In parallel with the high production of rice, agrochemicals have been increasingly and intensively applied. On average in the VMD, pesticide active ingredients (a.i) are typically applied on average 7.2/times per crop, totaling $1.8 \mathrm{~kg}$ per hectare [1]. In recent years, the average application rate of pesticide use per crop has decreased slightly for non-IPM (Integrated Pest Management) rice farmers, while it has more than doubled among IPM farmers [2]. Currently found in more than 150 commercial trade names of pesticide in Vietnam, Chlorpyrifos ethyl is one of the most commonly used insecticides in agriculture, particularly for rice cultivation [3,4]. The concentration of this insecticide in water after rice crop application has been found to vary between $4.23 \mu \mathrm{g} / \mathrm{L}$ and $5.25 \mu \mathrm{g} / \mathrm{L}$ [5]. It belongs to the organophosphate group, does not persist in the environment but is highly toxic to vertebrates and invertebrates through inhibiting cholinesterase activity [6]. A median lethal concentration (LC50-96 h) of this active ingredient was found to be 0.022 ppm for fry tilapia Oreochromis mossambicus [7] and $0.92 \mathrm{mg} / \mathrm{L}$ for fingerling Clarias gariepinus [8].

Silver barb (Barbonymus gonionotus) is a fish indigenous to a variety of water bodies in the VMD [9] and is also a common species cultivated in rice-fish systems [10]. Therefore, the species is at high risk of exposure to chlorpyrifos ethyl detected in rice paddy 
water. Organophosphate diazinon was found to cause prolonged cholinesterase (ChE) inhibition [11] and growth inhibition for air-breathing Channa striata at a concentration of $0.35 \mathrm{mg} / \mathrm{L}$ [12] under laboratory conditions. The Silver barb is solely a water-breathing fish species, which cannot shift to air-breathing if exposed to contaminated water. Therefore, the species may be more sensitive to pesticides, particularly at environmentally realistic concentrations. This study aims to determine the effects of chlorpyrifos ethyl on brain $\mathrm{ChE}$ activity and growth of silver barb under laboratory conditions.

\section{Methodology}

\subsection{Test Animals}

The Silver barb (weight 3-5 g) used in the experiments were purchased from a fish selling station in Chau Thanh district, Hau Giang province, Vietnam. The fish fingerlings were acclimatized in $600 \mathrm{~L}$ fiber-glass tanks under wet lab conditions for two weeks. During this acclamation phase, water was aerated continuously to maintain dissolved oxygen above $4 \mathrm{mg} / \mathrm{L}$ and exchanged daily at approximately $50 \%$ water volume. Fish were fed twice a day with commercial Cargill pellets, containing $30 \%$ protein at approximately $5 \%$ of total body wet weight. The feeding was stopped a day before the start of the experiment in order to limit excreted products that could contaminate the water in the experiments.

\subsection{Pesticide}

A commercially available product, Vitashield 40EC (containing 40\% chlorpyrifos ethyl $(\approx 1.141 \mathrm{~mol} / \mathrm{L})$, and inert ingredients including emulsifiers and solvents), was purchased from the Thanh Son Hoa Nong Company in Vietnam.

\subsection{Experimental Design}

\subsubsection{Acute Toxicity Testing}

Toxicity testing was performed in two steps [13]. First, a range-finding test was performed, followed by a 96-h static non-renewable water test using a $60 \mathrm{~L}$ glass-fiber tank containing $20 \mathrm{~L}$ of pesticide solutions. Following the range-finding test, the $96-\mathrm{h}$ static nonrenewable water test was performed using nominal concentrations of $0.1,0.150$, $0.275,0.450,0.750$ and $1.250 \mathrm{ppm}$ of chlorpyrifos ethyl and the control (tap water after $48 \mathrm{~h}$ continuous aeration to remove chlorine). Each treatment was triplicated. Ten healthy fishes were chosen from the acclimated tanks and carefully placed into each experimental tank. Temperature, $\mathrm{pH}$, and dissolved oxygen were measured twice a day in the morning (7:00-8:00 AM) and in the afternoon (2:00-3:00 PM) using $\mathrm{pH}$ and DO meters. Dead fish were removed from the tanks to minimize DO depletion. Mortality was recorded at 1, 3, 6, $9,12,24,36,48,72,84$ and $96 \mathrm{~h}$ after exposure.

2.3.2. Effect of Sub-Acute Concentrations of Chlorpyrifos Ethyl on the Brain Cholinesterase Activity of Silver Barb

Three nominal levels of chlorpyrifos ethyl $(1.19,11.9$ and $23.8 \mathrm{ppb})$ equivalent to $1 \%, 10 \%, 20 \%$ of LC50-96 h) and a control treatment (Tap water after $48 \mathrm{~h}$ continuous aeration to remove chlorine) were conducted in a $60 \mathrm{~L}$ glass aquaria containing $20 \mathrm{~L}$ of pesticide solutions with three replications. Each replication contained 25 healthy fish. During the experiment, the solution was not changed. Fish were not fed for $96 \mathrm{~h}$ and then feeding commenced one time a day using the commercial Cargill pellets. After one hour of feeding, uneaten pellets were collected to minimize water quality depletion. Two fish were randomly caught from each tank prior to exposure and at 3, 6, 9, 12, 24, 48, 72, 96, 168, and $336 \mathrm{~h}$ after exposure and immediately killed on ice and processed for $\mathrm{ChE}$ analysis [14]. Dissolved oxygen, $\mathrm{pH}$ and temperature were measured daily at 7:00 AM and again at 2:00 PM.

\section{Sample preparation}

All steps were performed on ice. The whole brain was dissected out and placed in a pre-weighed Eppendorf before measuring its weight. The brain tissue was homogenized 
and diluted in $0.1 \mathrm{M}$ phosphate buffer ( $\mathrm{pH} 7.4$ ) at a concentration of approximately $20 \mathrm{mg}$ fresh tissue per milliliter using a glass homogenizer (Uniform, Jencons PLC, Leighton Buzzard, UK). The homogenizer was rinsed with acetone (Merck, Darmstadt, Germany) and distilled water between samples.

\section{Cholinesterase assay}

Brain homogenates were centrifuged at $2000 \mathrm{rpm}$ and $4{ }^{\circ} \mathrm{C}$ for $20 \mathrm{~min}$ (Centrifuge $4 \mathrm{k} 15$, Sigma, Osterode am Harz, Germany). Six hundred micro-litters $(600 \mathrm{~mL})$ of the supernatant were removed to an Eppendorf tube and kept on ice for $\mathrm{ChE}$ analysis within $5 \mathrm{~h}$. All measurements were done in an air-conditioned room at $25^{\circ} \mathrm{C}$. ChE activity was measured according to the method described by Ellman et al. [14] with minor modifications described in Cong et al. [11]. ChE activity was detected using an U2900 Spectrophotometer (HITACHI, Tokyo, Japan) for $200 \mathrm{~s}$ at $412 \mathrm{~nm}$. The $\mathrm{r}^{2}$ value of the absorbance curves used to calculate the rate coefficients were in all cases higher than 0.9. The results of these measurements were expressed as a rate (Delta absorbance per minute) and the ChE activity was calculated.

\subsubsection{Effect of Sub-Acute Concentrations of Chlorpyrifos Ethyl on the Growth of} Silver Barb

Three nominal levels of chlorpyrifos ethyl $(1.19,11.9$, and $23.8 \mathrm{ppb})$ and a control (Tap water) were conducted in $600 \mathrm{~L}$ glass-fiber tanks with three replications. Each tank contained $300 \mathrm{~L}$ of pesticide solution or tap water (for control treatment). After preparing pesticide solutions, the water in the tanks was mixed for $5 \mathrm{~min}$ and $1 \mathrm{~L}$ of water was collected for detecting the actual concentration of chlorpyrifos ethyl using GC-MS [15]. Thereafter, thirty healthy fish were individually weighed and placed into each tank. The tank water was continuously aerated to prevent DO depletion. Fish were fed from the second day after exposure at $5 \%$ total body wet weight using commercial Cargill pellets. Uneaten pellets were collected one hour after feeding for calculation of feed intake. The parameters of $\mathrm{DO}, \mathrm{pH}$, temperate, $\mathrm{NO}_{2}{ }^{-}, \mathrm{NH}_{3} / \mathrm{NH}_{4}{ }^{+}$were checked once every three days. Fish weights were checked every 15 days and thereafter chlorpyrifos ethyl concentrations were renewed correspondingly to the initial levels. Dead fish during the experiment were recorded and weighed calculating feed conversion ratio (FCR) in each treatment. The experiment lasted for 60 days.

\subsubsection{Calculation}

Food intake (FI) was calculated as follows:

$$
\mathrm{FI}=\frac{\Sigma \mathrm{Fc}-\Sigma \mathrm{Fr}}{\Sigma \mathrm{W} \times \mathrm{t}}
$$

where: FI is the amount of feed consumed (mg/g of fresh fish weight/day); $\sum \mathrm{F}_{\mathrm{c}}$ is the total amount of feed supplied (mg); $\sum F_{r}$ is the total amount of feed unused (mg); $\sum \mathrm{W}$ is the total weight of fish at time $t(\mathrm{~g})$; $t$ is the time period of the experiment (day).

Specific growth rate (SGR) was calculated as follows:

$$
\mathrm{SGR}=\frac{\ln \mathrm{Wt}-\ln \mathrm{W} 0}{\mathrm{t}} \times 100
$$

where: SGR is specific growth rate (\%/day); $\mathrm{W}_{0}$ is the initial weight $(\mathrm{g}) ; \mathrm{W}_{\mathrm{t}}$ is the final weight $(\mathrm{g}) ; \mathrm{t}$ is the time period of the experiment (day).

Feed Conversion Ratio (FCR) was calculated as follows:

$$
\mathrm{FCR}=\frac{\Sigma \mathrm{Fc}-\Sigma \mathrm{Fr}}{\Sigma \mathrm{Wf}-\Sigma \mathrm{Wi}+\Sigma W \mathrm{~m}}
$$


where: FCR is feed conversion ratio; $\sum \mathrm{F}_{\mathrm{c}}$ is total amount of supplied feed $(\mathrm{g}) ; \sum \mathrm{F}_{\mathrm{r}}$ is total amount of unconsumed feed $(\mathrm{g}) ; \sum \mathrm{W}_{\mathrm{f}}$ is total final weight of fish $(\mathrm{g}) ; \sum \mathrm{W}_{\mathrm{i}}$ is total initial weight of fish (g); $\sum W_{m}$ is total weight of dead fish $(\mathrm{g})$.

Survival rate was determined as follows:

$$
\mathrm{SR}=\frac{\sum \text { survial fish }}{\sum \text { total experimenting fish }} \times 100
$$

\subsubsection{Data Analysis}

The LC50-96 h value of chlorpyrifos ethyl was estimated by probit analysis [16]. Differences in ChE activity and growth performances among treatments were analyzed using a one-way analysis of variance and Duncan's test in SPSS for Windows, version 19.0 (IBM Corp., Armonk, NY, USA). Significant difference were considered at $p<0.05$.

\section{Results and Discussion}

\subsection{The $L C_{50}-96$ h of Chlorpyrifos Ethyl for Fingerling Silver Barb}

Water temperature in the experimental tanks varied between $26.8 \pm 0.3{ }^{\circ} \mathrm{C}$ and $28.9 \pm 0.2^{\circ} \mathrm{C}$ (Table 1). Water $\mathrm{pH}$ was more stable, fluctuating between $7.1 \pm 0.0$ and $7.2 \pm 0.1$, while DO varied between $2.8 \pm 0.5 \mathrm{mg} / \mathrm{L}$ and $3.6 \pm 0.7 \mathrm{mg} / \mathrm{L}$ among treatments during the experiment. Environmental parameters were not significantly different among treatments.

Table 1. Temperature, $\mathrm{pH}$ and DO of water in experimental tanks.

\begin{tabular}{ccccccc}
\hline \multirow{2}{*}{ Chlorpyrifos Ethyl (ppm) } & \multicolumn{2}{c}{ Temperature $\left({ }^{\circ} \mathbf{C}\right)$} & \multicolumn{2}{c}{ pH } & \multicolumn{2}{c}{ DO (mg/L) } \\
\cline { 2 - 6 } & Morning & Afternoon & Morning & Afternoon & Morning & Afternoon \\
\hline Control & $26.8 \pm 0.3$ & $28.6 \pm 0.5$ & $7.1 \pm 0.1$ & $7.1 \pm 0.1$ & $3.6 \pm 0.7$ & $2.8 \pm 0.5$ \\
0.100 & $26.9 \pm 0.3$ & $28.5 \pm 0.5$ & $7.1 \pm 0.0$ & $7.1 \pm 0.2$ & $3.5 \pm 0.5$ & $3.1 \pm 0.6$ \\
0.150 & $26.9 \pm 0.3$ & $28.7 \pm 0.4$ & $7.1 \pm 0.1$ & $7.1 \pm 0.1$ & $3.3 \pm 0.4$ & $3.0 \pm 0.3$ \\
0.275 & $26.8 \pm 0.3$ & $28.9 \pm 0.2$ & $7.1 \pm 0.0$ & $7.1 \pm 0.2$ & $3.4 \pm 0.3$ & $3.2 \pm 0.4$ \\
0.450 & $27.0 \pm 0.1$ & $28.4 \pm 0.5$ & $7.2 \pm 0.1$ & $7.1 \pm 0.1$ & $3.5 \pm 1.3$ & $3.0 \pm 1.0$ \\
0.750 & $26.8 \pm 0.3$ & $28.5 \pm 0.4$ & $7.2 \pm 0.1$ & $7.1 \pm 0.2$ & $3.3 \pm 1.1$ & $3.2 \pm 1.0$ \\
1.250 & $27.0 \pm 0.2$ & $28.6 \pm 0.4$ & $7.2 \pm 0.1$ & $7.2 \pm 0.1$ & $3.4 \pm 1.2$ & $3.4 \pm 1.1$ \\
\hline
\end{tabular}

Data are presented as mean $\pm \mathrm{SD}, n=12$.

No mortality occurred in the control treatment. The mortality of the fish generally depended on both concentration and duration of exposure. The higher dose caused a higher mortality rate, while longer exposure also resulted in a higher mortality rate. However, trends of mortality rate were not seen after $60 \mathrm{~h}$ (Figure 1-left).

As regards the results for mortality, an estimation using the probit method showed that the LC50-96 h of chlorpyrifos ethyl for fingerling Silver barb was $0.119 \mathrm{ppm}$. The $96 \mathrm{~h}-$ LC50 value of chlorpyriphos ethyl was found to be $0.022 \mathrm{ppm}$ for Oreochromis mossambicus fry [7] and $0.92 \mathrm{mg} / \mathrm{L}$ for fingerling Clarias gariepinus [8]. The current study indicates that Silver barb is more resistant to chlorpyrifos ethyl than Tilapia, but it is more sensitive to this ingredient than the airbreathing fish C. gariepinus. This value is lower than in air-breathing fish species such as snakehead fish Channa striata [17], and catfish, Mystus vittatus [18] which can air-breath when placed in contaminated water. 

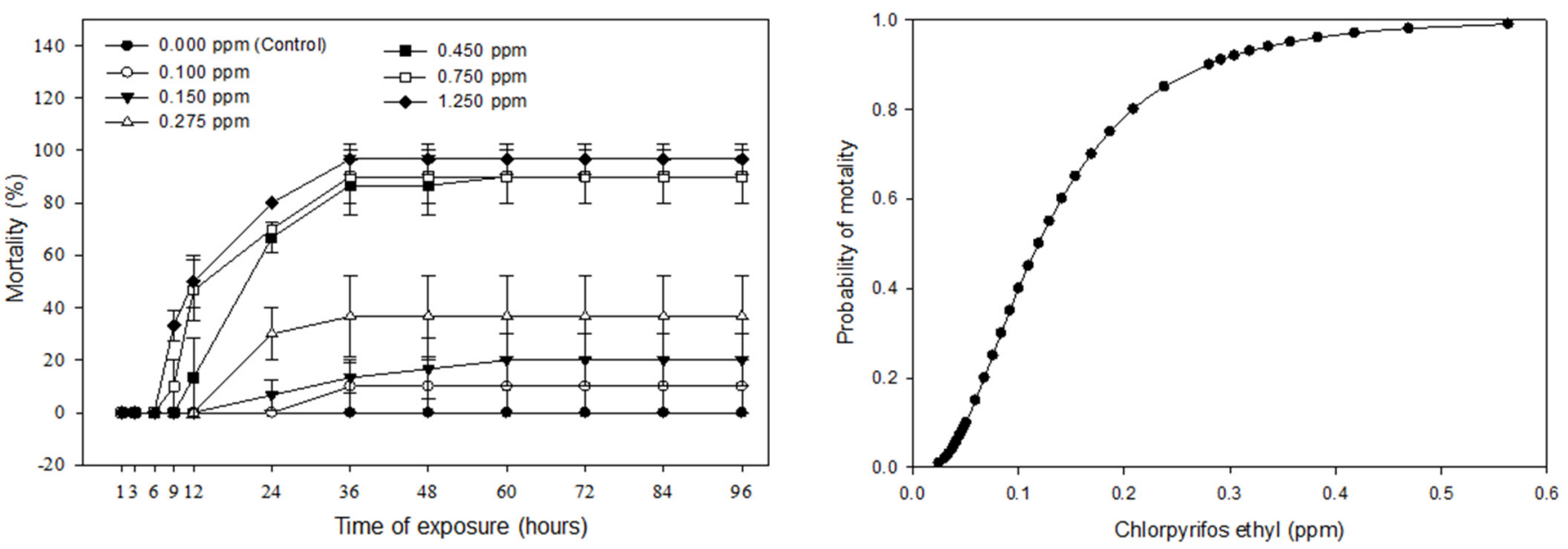

Figure 1. Mortality responses to exposure doses (left) and relationship between concentration of chlorpyrifos ethyl and mortality probability at $96 \mathrm{~h}$ (right).

\subsection{Effects of Sub-Acute Concentrations of Chlorpyrifos Ethyl on ChE Activity}

This sub-lethal experiment was carried out with water temperature conditions of within $28.1 \pm 0.1-29.9 \pm 0.1^{\circ} \mathrm{C}$; values of water $\mathrm{pH}$ were $7.1 \pm 0.1-7.3 \pm 0.2$ and $\mathrm{DO}$ was $2.7 \pm 0.02-4.0 \pm 0.02 \mathrm{mg} / \mathrm{L}$ (Table 2). These mean values were similar among treatments in the morning or afternoon measurements. No death of fish occurred before sampling in all treatments.

Table 2. Temperature, $\mathrm{pH}$ and $\mathrm{DO}$ of water in sub-acute experimental tanks.

\begin{tabular}{ccccccc}
\hline \multirow{2}{*}{ Chlorpyrifos Ethyl $(\mathbf{p p b})$} & \multicolumn{2}{c}{ Temperature $\left({ }^{\circ} \mathbf{C}\right)$} & \multicolumn{2}{c}{ pH } & \multicolumn{2}{c}{ DO (mg/L) } \\
\cline { 2 - 7 } & Morning & Afternoon & Morning & Afternoon & Morning & Afternoon \\
\hline Control & $28.1 \pm 0.1$ & $29.5 \pm 0.1$ & $7.1 \pm 0.1$ & $7.3 \pm 0.1$ & $4.0 \pm 0.02$ & $2.9 \pm 0.03$ \\
1.19 & $28.2 \pm 0.1$ & $29.9 \pm 0.1$ & $7.1 \pm 0.0$ & $7.3 \pm 0.2$ & $3.9 \pm 0.04$ & $2.8 \pm 0.02$ \\
11.9 & $28.1 \pm 0.1$ & $29.6 \pm 0.1$ & $7.1 \pm 0.1$ & $7.3 \pm 0.1$ & $3.8 \pm 0.04$ & $2.9 \pm 0.02$ \\
23.8 & $28.3 \pm 0.1$ & $29.6 \pm 0.1$ & $7.1 \pm 0.0$ & $7.3 \pm 0.2$ & $3.8 \pm 0.02$ & $2.7 \pm 0.02$ \\
\hline
\end{tabular}

Data are presented as mean $\pm \mathrm{SD}, n=12$.

Results showed that the levels of ChE inhibition increased and reached a peak at $24 \mathrm{~h}$ following exposure, and thereafter decreased (Figure 2). In all sub-acute concentrations, chlorpyrifos ethyl caused significant $\mathrm{ChE}$ inhibition during $96 \mathrm{~h}$ of exposure. In the lowest concentration (1.19 ppb), ChE inhibition was found to be fully recovered at one week post-exposure, while in the treatment with 10\% LC50-96 h (11.9 ppb) and 20\% LC50-96 h (23.8 ppm) ChE was still significantly inhibited. Following $330 \mathrm{~h}$ (15 days) of exposure, $\mathrm{ChE}$ inhibition in the highest concentration was still significantly different from the control treatment.

Most aquatic organisms died when their ChE inhibition reached more than $70 \%$, while abnormal activities were found in most cases of ChE inhibition over 30\% of normal activity [19]. In the present study, despite the lowest chlorpyrifos ethyl concentration (1\%LC50-96 $\mathrm{h} \# 1.19 \mathrm{ppb}), \mathrm{ChE}$ inhibition was significant to the control, and the maximum $\mathrm{ChE}$ inhibited rate was $17 \%$. This suggests that this lowest observed effect concentration (LOEC) for ChE may not cause negative effects for Silver barb. In the remaining two treatments (10\% and 20\% LC50-96 h), ChE inhibition was over 30\% after $6 \mathrm{~h}$ of exposure and remained for a week for the 10\% LC50-96 h treatment and 2 weeks for the highest concentration. A negative correlation between swimming speed and ChE activity was reported in the case of Oncorynchus mykiss exposed to carbamate carbaryl [20], diazinon and malathion [21]. In the present study, although swimming speed was not investigated, the fish in high concentrations were much easier to catch than fish in the control treatment. 
Swimming inhibition may negatively affect fish ability to avoid predators, or hunting for food in natural habitats.

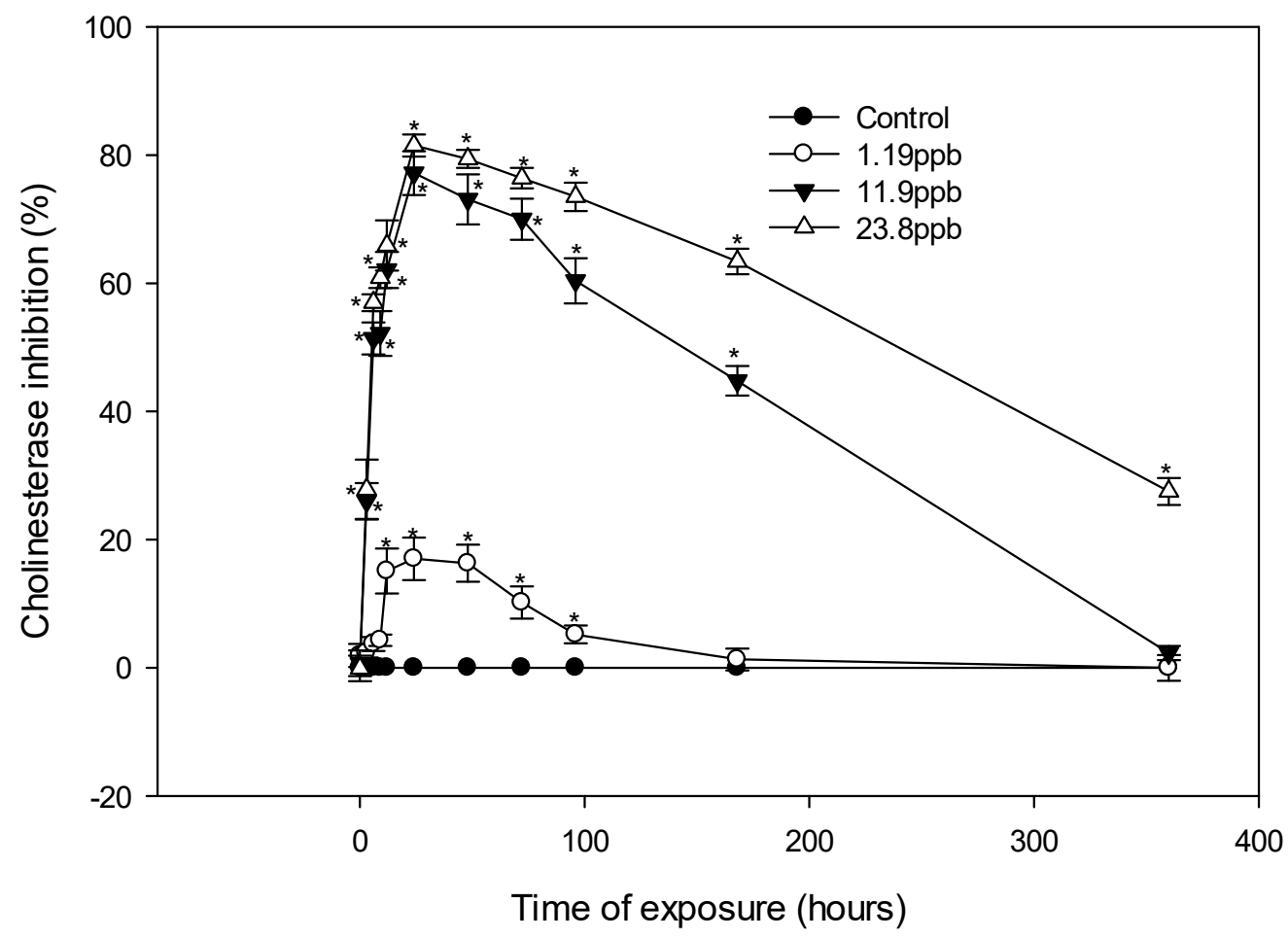

Figure 2. Trends of ChE inhibition after one exposure. Data are presented as the mean of 6 fish, with vertical bars representing the standard error. An asterisk $\left(^{*}\right)$ indicates significant difference to parallel control $(p<0.05)$.

\subsection{Effects of Sub-Acute Chlorpyrifos Ethyl on the Growth Performance of Silver Barb}

Water from each treatment was collected immediately after preparation of the exposed solutions to check the actual chlorpyrifos ethyl concentrations. Results showed that actual concentration of chlorpyrifos ethyl in the control was less than the detection limit $(0.1 \mu \mathrm{g} / \mathrm{L})$, whereas actual concentration in the treatment of 1,10 and $20 \%$ LC50-96 h was $0.66,10.43$ and $22.97 \mu \mathrm{g} / \mathrm{L}$, respectively (Table 3 ).

Table 3. Actual concentrations of chlorpyrifos ethyl in the growth performance experiment.

\begin{tabular}{ccc}
\hline Treatment & Vitashield 40EC $(\mathbf{p p b})$ & Actual Chlorpyrifos Ethyl $(\mu \mathrm{g} / \mathrm{L})$ \\
\hline Control & Tap water & $<\mathrm{MDL}=0.1 \mu \mathrm{g} / \mathrm{L}$ \\
1\% LC50 & 3.0 & $0.66(0.58 \div 0.78)$ \\
10\% LC50 & 30.0 & $10.43(9.60 \div 11.20)$ \\
20\% LC50 & 60.0 & $22.97(22.10 \div 23.80)$ \\
\hline
\end{tabular}

Results showed that environmental conditions did not vary greatly among treatments (Table 4).

The growth performances of the Silver barb over 60 days were recorded and analyzed (Table 5). The result showed that feed intake (FI) in the control was $20.3 \mathrm{mg} / \mathrm{g} / \mathrm{d}$ and increased in treatments with higher concentrations of chlorpyrifos ethyl. A similar trend was seen for the FCR, while the opposite trends were seen for DWG and SGR. In the 10\% and 20\% LC50-96 h treatments, DWG, SGR and FCR were all significantly different from the control treatment. 
Table 4. Environmental conditions of experiment tanks during the growth performance experiment.

\begin{tabular}{|c|c|c|c|c|c|}
\hline \multirow{2}{*}{ Environmental Parameters } & \multirow{2}{*}{ Time } & \multicolumn{4}{|c|}{ Treatment } \\
\hline & & Control & $1 \%$ LC50-96 h & $10 \%$ LC50-96 h & $20 \%$ LC50-96 h \\
\hline \multirow{2}{*}{ Temperature $\left({ }^{\circ} \mathrm{C}\right)$} & M & $27.79 \pm 0.12$ & $27.72 \pm 0.12$ & $27.74 \pm 0.12$ & $27.77 \pm 0.13$ \\
\hline & A & $28.74 \pm 0.12$ & $28.72 \pm 0.12$ & $28.72 \pm 0.13$ & $28.77 \pm 0.13$ \\
\hline \multirow{2}{*}{$\mathrm{pH}$} & $M$ & $7.50 \pm 0.02$ & $7.51 \pm 0.02$ & $7.52 \pm 0.02$ & $7.53 \pm 0.02$ \\
\hline & $\mathrm{A}$ & $7.44 \pm 0.02$ & $7.45 \pm 0.02$ & $7.47 \pm 0.02$ & $7.47 \pm 0.02$ \\
\hline \multirow{2}{*}{$\mathrm{DO}(\mathrm{mg} / \mathrm{L})$} & $\mathrm{M}$ & $7.19 \pm 0.06$ & $7.15 \pm 0.07$ & $7.21 \pm 0.07$ & $7.26 \pm 0.06$ \\
\hline & A & $6.69 \pm 0.09$ & $6.65 \pm 0.11$ & $6.75 \pm 0.11$ & $6.77 \pm 0.1$ \\
\hline \multirow{2}{*}{$\mathrm{N}-\mathrm{NO}_{2}(\mathrm{mg} / \mathrm{L})$} & M & $0.308 \pm 0.047$ & $0.340 \pm 0.049$ & $0.347 \pm 0.051$ & $0.362 \pm 0.049$ \\
\hline & A & $0.254 \pm 0.041$ & $0.334 \pm 0.044$ & $0.388 \pm 0.050$ & $0.339 \pm 0.050$ \\
\hline \multirow{2}{*}{$\mathrm{N}-\mathrm{NH}_{4}(\mathrm{mg} / \mathrm{L})$} & M & $0.232 \pm 0.06$ & $0.241 \pm 0.052$ & $0.206 \pm 0.047$ & $0.449 \pm 0.13$ \\
\hline & $\mathrm{A}$ & $0.241 \pm 0.046$ & $0.249 \pm 0.046$ & $0.317 \pm 0.053$ & $0.413 \pm 0.103$ \\
\hline
\end{tabular}

Note: $\mathrm{M}=$ Morning, $\mathrm{A}=$ Afternoon.

Table 5. Growth performances of B. gonionotus after 60 days.

\begin{tabular}{|c|c|c|c|c|}
\hline \multirow{2}{*}{ Growth Parameters } & \multicolumn{4}{|c|}{ Treatments } \\
\hline & Control & $1 \%$ LC50-96 h & $10 \%$ LC50-96 h & $20 \%$ LC50-96 h \\
\hline $\mathrm{FI}(\mathrm{mg} / \mathrm{g} / \mathrm{d})$ & $20.3 \pm 0.4^{a}$ & $20.4 \pm 0.5^{\mathrm{a}}$ & $21.2 \pm 0.5^{\mathrm{a}}$ & $22.1 \pm 1.5^{a}$ \\
\hline $\operatorname{DWG}(\mathrm{mg} / \mathrm{d})$ & $95.2 \pm 4.9^{\mathrm{a}}$ & $92.8 \pm 2.3^{a}$ & $75.5 \pm 2.0^{b}$ & $60.6 \pm 2.9^{c}$ \\
\hline SGR $(\% / d)$ & $1.86 \pm 0.04^{\mathrm{a}}$ & $1.84 \pm 0.01^{\mathrm{a}}$ & $1.61 \pm 0.02^{b}$ & $1.39 \pm 0.03^{c}$ \\
\hline FCR & $1.82 \pm 0.06^{\mathrm{a}}$ & $1.83 \pm 0.03^{\mathrm{a}}$ & $2.05 \pm 0.05^{b}$ & $2.34 \pm 0.22^{c}$ \\
\hline
\end{tabular}

Data are presented as mean \pm SD. In the same row, data follow the same letter is not significant different $(p>0.05$, Duncan test). FI: Food intake, DWG: Daily weight gain, SGR: Specific growth rate, FCR: Feed conversion ratio.

Living in stressed conditions such as pesticide-contaminated water, most fish may require more energy to maintain basic metabolic functions, resulting in fish increased food intake. Increased food consumption rates were reported for zebra fish, Danio rerio, after chronic exposure to parathion [22], and for snakehead fish Channa striata after chronic exposure to diazinon [12]. In the present study, the food intake increased in the higher concentrations of chlorpyrifos ethyl. The exposed Silver barb may also need more energy for detoxification. The significantly higher FCR in the 10\% LC50-96 h and 20\% LC50-96 h $(p<0.05)$ of this study suggest that fish needed more food to gain each unit of body biomass. Consequently, it resulted in lower DWG and SGR (Table 5).

The results indicate that with repeated exposure to chlorpyrifos ethyl (15 days interval), no observed effect concentration (NOEC) for growth was seen at the 1\% LC50-96 $\mathrm{h}$ treatment $(0.66 \mu \mathrm{g} / \mathrm{L}$ for actual concentration). However, growth inhibitions were seen at the concentration of $10 \% \mathrm{LC} 50-96 \mathrm{~h}(9.60 \div 11.20 \mu \mathrm{g} / \mathrm{L}$ for actual concentration) or higher. The concentrations of chlorpyrifos ethyl in rice field water in the VMD were reported in the range of $3.75 \pm 1.15 \mu \mathrm{g} / \mathrm{L}$ to $5.35 \pm 2.28 \mu \mathrm{g} / \mathrm{L}$ [5] and $4.65 \pm 2.92 \mu \mathrm{g} / \mathrm{L}$ [23]. In addition, in the triple rice crops zone, water concentrations of chlorpyrifos were found to be $24.5-39.4 \mu \mathrm{g} / \mathrm{L}$ within the rice field, $8.2-14.5 \mu \mathrm{g} / \mathrm{L}$ within the canal within rice field and 4.1-9 $\mu \mathrm{g} / \mathrm{L}$ in adjacent rivers (Pham Hung Cuong-Master thesis of Environmental Sciences, Can Tho University, Vietnam-Unpublished data). These concentrations are already within the range of causing $\mathrm{ChE}$ and growth inhibition in Silver barb. In contrast to the $\mathrm{ChE}$ activity endpoint, growth performances are less sensitive to chlorpyrifos ethyl than $\mathrm{ChE}$. At the concentration of $1.19 \mathrm{ppm}$, chorpyrifos ethyl has already caused significant $\mathrm{ChE}$ inhibition, yet growth effects are seen at concentraion of $11.9 \mathrm{ppm}$. In the present study, after two weeks at 20\% LC50-96 h, ChE was still seen to be inhibited by more than $30 \%$. The pesticide is used several times per rice-crop (\#100 days) [1-3]. Therefore, if the species is cultivated in rice-fish systems or resides in adjacent water bodies nearby, its 
ChE activity may not be fully recovered and may undergo repeated stress episodes from renewed pesticide applications.

\section{Conclusions}

This study found that chlorpyrifos ethyl is highly toxic to fingerling Silver barb with the $\mathrm{LC}_{50}-96 \mathrm{~h}$ of $0.119 \mathrm{ppm}$. The lowest observed effect concentration (LOEC) was $1 \%$ $\mathrm{LC}_{50}-96 \mathrm{~h}$ for $\mathrm{ChE}$ and $10 \% \mathrm{LC}_{50}-96 \mathrm{~h}$ for growth. The no observed effect concentration (NOEC) of chlorpyrifos ethyl for growth was $1 \% \mathrm{LC}_{50}-96 \mathrm{~h}$. The result from this study implies that $\mathrm{ChE}$ activity would be significantly inhibited at environmentally realistic concentrations of the VMD. Brain ChE of this species can be used as biomarker of exposure to chlorpyrifos ethyl contaminant. Further studies in the rice fields, as well as in the canals or adjacent rivers, should be undertaken.

Author Contributions: Conceptualization, N.V.C. and T.S.N.; methodology, N.V.C. and D.T.D.; software, D.T.D.; validation, N.V.C., T.S.N. and D.T.D.; formal analysis, D.T.D.; investigation, N.V.C. and D.T.D.; resources, N.V.C., T.S.N. and D.T.D.; data curation, N.V.C., T.S.N. and D.T.D.; writingoriginal draft preparation, N.V.C. and D.T.D.; writing — review and editing, N.V.C., T.S.N. and D.T.D.; visualization, N.V.C., T.S.N. and D.T.D.; supervision, N.V.C.; project administration, T.S.N.; funding acquisition, N.V.C. All authors have read and agreed to the published version of the manuscript.

Funding: This research received no external funding.

Institutional Review Board Statement: Not applicable.

Informed Consent Statement: Not applicable.

Acknowledgments: This study is funded in part by the Can Tho University Improvement Project VN14P6 supported by a Japanese ODA loan. The authors would like to thank Nigel K. Downes-Researcher for Integrated Water Resource Management (IWRM) for proofreading the article.

Conflicts of Interest: The authors declare no conflict of interest.

\section{References}

1. Berg, H. Pesticide use in rice and rice-fish farms in the Mekong Delta, Vietnam. Crop Prot. 2001, 20, 897-905. [CrossRef]

2. Berg, H.; Tam, N.T. Use of pesticides and attitude to pest management strategies among rice and rice-fish farmers in the Mekong Delta, Vietnam. Int. J. Pest Manag. 2012, 58, 153-164. [CrossRef]

3. Toan, N.V.; Cong, N.V. Present status of pesticide uses in rice cultivation in the Mekong Delta. J. Nat. Resour. Environ. 2018, 5, 26-30.

4. MARD (Ministry of Agriculture and Rural Development). List of Pesticides Permitted, Restricted, and Banned for Use; MARD: Hanoi, Vietnam, 9 September 2020; Circular No. 10/2020/TT-BNNPTNT. (In Vietnamese)

5. Tam, N.T.; Berg, H.; Laureus, J.; Cong, N.V.; Tedengren, M. Effects of Sequential Applications of Bassa 50EC (Fenobucarb) and Vitashield 40EC (Chlorpyrifos ethyl) on Acetylcholinesterase Activity in Climbing Perch (Anabas testudineus) Cultured in Rice Fields in the Mekong Delta, Vietnam. Bull. Environ. Contam. Toxicol. 2016, 97, 98-104. [CrossRef] [PubMed]

6. Stenersen, J. Chemical Pesticides. Mode of Action and Toxicity; CRC Press: Boca Raton, FL, USA; London, UK, $2004 ;$ pp. 90-113.

7. Muttappa, K.; Reddy, H.R.V.; Padmanabha, A.; Shridhar, B.; Prabhudeva, K.N.; Basavaraju, Y.; Gangadhar, G.; Rajanna, K.B.; Chethan, N. Chlorpyrifos induced histological changes in the liver of tilapia (Oreochromis mossambicus). Int. J. Recent Sci. Res. 2015, 6, 5819-5823.

8. Ogueji, E.O. Comparative acute toxicity of chlorpyrifos-ethyl (organophosphate) and lambda-cyhalothrin (Pyrethroid) to the African catfish (C. gariepinus) using some biochemical parameters. Glob. J. Pure Appl. Sci. 2008, 14, 263-269. [CrossRef]

9. Khoa, T.T.; Huong, T.T.T. Classification of Fresh Water Fish of the Mekong River Delta, Vietnam; Cantho University Press: Cantho City, Vietnam, 1993. (In Vietnamese)

10. Rothuis, A.J.; Nhan, D.K.; Richter, C.J.J.; Ollevier, F. Rice with fish culture in the semi-deep waters of the Mekong Delta, Vietnam: A socio-economical survey. Aquac. Res. 1998, 29, 47-571. [CrossRef]

11. Cong, N.V.; Phuong, N.T.; Bayley, M. Sensitivity of brain cholinesterase activity to diazinon (Basudin 50EC) and fenobucarb (Bassa 50EC) insecticides in the air-breathing fish Channa striata (Bloch, 1793). Environ. Toxicol. Chem. 2006, 25, 1418-1425. [CrossRef] [PubMed]

12. Cong, N.V.; Phuong, N.T.; Bayley, M. Effects of repeated exposure of diazinon on cholinesterase activity and growth in snakehead (Channa striata). Ecotoxicol. Environ. Saf. 2009, 72, 699-703. [CrossRef] [PubMed]

13. APHA. Standard Methods for the Examination of Water and WastWater, 15th ed.; American Public Health Association: Washington, DC, USA, 1998; p. 1134. 
14. Ellman, G.L.; Courtney, D.; Anderdres, V.J.; Featherstone, R.M. A new and rapid colorimetric determination of acetylcholinesterase activity. Biochem. Pharm. 1961, 7, 88-95. [CrossRef]

15. Parfitt, C.H. Pesticide and Industrial Chemical Residues. In Official Methods of Analysis of AOAC International, 17th ed.; Horwitz, W., Ed.; Vol 1-Agrochemicals; Contaminants; Drugs; Association of Analytical Communities International: Gaithersburg, MD, USA, 2000; pp. 22-23.

16. Finney, D.J. Probit Analysis, 3rd ed.; Cambridge University Press: London, UK, 1971; pp. $20-49$.

17. Cong, N.V.; Phuong, N.T.; Bayley, M. Effects of Sublethal Concentrations of Diazinon on Surfacing and Hanging Behaviors of Snakehead (Channa striata). Fish. Sci. 2008, 74, 1330-1332. [CrossRef]

18. Arunachalam, S.; Palanichamy, S. Sublethal Effects of Carbaryl on Surfacing Behaviour and Food Utilization in the Air-Breathing Fish, Macropodus cupanus. Physiol. Behav. 1982, 29, 23-27. [CrossRef]

19. Fulton, M.H.; Key, P.B. Acetylcholinesterase inhibition in estuarine fish and invertabrates as an indicator of Organophosphorus insecticide exposure and effects. Environ. Toxicol. Chem. 2001, 20, 37-45. [CrossRef] [PubMed]

20. Beauvais, S.L.; Jones, S.B.; Parris, J.T.; Brewer, S.K.; Little, E.E. Cholinergic and Behavioral Neurotoxicity of Carbaryl and Cadmium to Larval Rainbow Trout (Oncorhynchus mykiss). Ecotoxicol. Environ. Saf. 2001, 49, 84-90. [CrossRef] [PubMed]

21. Brewer, S.K.; Little, E.E.; DeLonay, A.J.; Beauvais, S.L.; Jones, S.B.; Ellersieck, M.R. Behavioral Dysfunctions Correlate to Altered Physiology in Rainbow Trout (Oncorynchus mykiss) Exposed to Cholinesterase-Inhibiting Chemicals. Arch. Environ. Contam. Toxicol. 2001, 40, 70-76. [PubMed]

22. Roex, E.W.M.; Vries, E.D.; van Gestel, C.A.M. Sensitivity of the zebrafish (Danio rerio) early life stage test for compounds with different modes of action. Environ. Poll. 2002, 120, 355-362. [CrossRef]

23. Tam, N.T.; Berg, H.; Cong, N.V. Evaluation of the joint toxicity of chlorpyrifos ethyl and fenobucarb on climbing perch (Anabas testudineus) from rice fields in the Mekong Delta, Vietnam. Environ. Sci. Pollut. Res. 2018, 25, 13226-13234. [CrossRef] [PubMed] 